Please cite this article as:

Reutterer, Thomas, Teller, Christoph. 2009. Store Format Choice and Shopping Trip Types. International Journal of Retail and Distribution Management, 37 (8), pp. 695-710. 


\title{
StORE Format ChOICE AND SHOPPING TRIP TYPES
}

\author{
Thomas Reutterer \\ Institute for Retailing and Marketing, Vienna University of Economics and Business \\ Administration, Augasse 2-6, A-1090 Vienna, Austria \\ TEL: ++43- (0) 1-31336-4619 \\ FAX: ++43- (0) 1-31336-717 \\ Email: thomas.reutterer@wu-wien.ac.at
}

Christoph Teller*

Institute for Retail Studies, University of Stirling

Stirling FK9 4LA, Scotland, United Kingdom

TEL: ++44 (0) 1786466454

FAX: ++44 (0) 1786465290

Email: christoph.teller@stir.ac.uk

*...corresponding author 


\section{Abstract}

Purpose: The purpose of the paper is to identify store format attributes that impact on store format choice when consumers conduct fill-in or major trips to buy groceries. By doing so, we take into consideration that consumers patronise multiple (store-based) formats depending on the shopping situation operationalised by the type of shopping trip.

Design/methodology/approach: The paper adopts the conceptual framework of random utility theory via application of a multinomial logit modelling framework. The analysis is based on a survey of 408 consumers representing households in a clearly defined central European retail area.

Findings: The results reveal a considerable moderating effect of the shopping situation on the relationship between perceived store format attributes and store format choice. Consumers' utilities are significantly higher for discount stores and hypermarkets when conducting major trips. To the contrary, supermarkets are preferred for fill-in trips in the focused retail market. Merchandise-related attributes of store formats have a higher impact on the utility formation regarding major-trips, whereas service- and convenience-related attributes do so regarding fill-in trips.

Research limitations: The findings can only be generalised to retail markets having similar characteristics like the one under study. It is highly concentrated, contains considerable share of small size retail stores, it is urban and has clear cut boundaries due to its geographical location.

Originality/value: This paper considers the fact that consumers patronise multiple store formats and investigates the moderating effect of the shopping situation - operationalised by different types of shopping trips - on store format choice.

Keywords: Grocery retailing, store choice modelling, multinomial logit, shopping trip, grocery retail marketing, store format competition, situational 


\section{Introduction}

Two prevalent trends can be observed in grocery retail markets, namely concentration and consolidation. The first trend describes the rising power of dominating retail chains, whereas the second one indicates the declining number of independent small retail enterprises and outlets (Colla, 2004; González-Benito, 2001). These trends are reflected in the competition between (retail) store formats where a shift of market share from small sized store formats $\left(<400 \mathrm{~m}^{2}\right.$; i.e. small supermarkets) to larger scale formats $\left(>800 \mathrm{~m}^{2}\right.$; i.e. large supermarkets, hypermarkets and discounters) can be observed (ACNielsen, 2004; Popkowski-Leszczyc and Timmermans, 2001). Driving this shift in behaviour is the increasing use of multiple stores and formats since they offer different opportunities to satisfy bundles of wants and needs depending on the shopping occasion (e.g., Cummins et al., 2008; Findlay and Sparks, 2008; McGoldrick and Andre, 1997; Uncles and Hammond, 1995).

Van Kenhove et al. (1999) stress the importance of the (shopping) task definition and thereby also including shopping occasion (e.g., urgent purchase, large quantities or regular purchase) towards store choice by investigating the phenomenon in a Do-lt-Yourself (DIY) setting. Gehrt and Yan (2004) provide a more complex insight into the moderating effect of the shopping situation and focus on the preference of store-based and non-store based formats. Nevertheless, they do not particularly consider grocery specific formats. With respect to grocery shopping Kahn and Schmittlein (1989/1992) indicate the impact of shopping occasion, in particular whether consumers make a major trip to stores or just a fillin trip (defined by whether the total expenditure or size of groceries were above or below the average expenditure on groceries, respectively) on store choice. Finally, Walters and Jamil (2003) show that different trip types influence shopping behaviour in general. Although, the amount of literature regarding store format patronage has been growing in recent years (e.g., González-Benito et al., 2005; Bhatnagar and Ratchford, 2004; Solgaard and Hansen, 2003; Messinger and Narasimhan, 1997) the moderating effect of the shopping occasion 
and/or shopping trip type has widely been neglected on this aggregated store perspective in the field of grocery retailing (Gehrt and Yan, 2004).

Due to the increasing relevance of inter-store-format competition and the identified research gap this paper aims to identify the role of shopping occasions operationalised by different shopping trip types as a moderating variable on store format choice in a grocery retailing setting. Contextually, we focus on an aggregated store perspective where formats are understood as a representation of stores where (retail) marketing strategies and actions (e.g. location, product range, price level, atmospherics) are applied in a stereotypical, format specific way.

The remainder of the article is organised as follows: After these introductory remarks a conceptual framework and the analytical model is presented in more detail. Based on that hypotheses are set up and background information about the empirical research approach (survey, sample size, variables observed) are presented. Consequently, results are reported followed by a discussion of the implications of the empirical findings and some remaining issues potentially stimulating future research endeavours are addressed.

\section{Conceptual framework and model description}

In order to investigate store format choice with respect to different shopping occasions we decided to apply Random Utility Theory (RUT). The basic assumption of RUT is that each consumer $c=1, \ldots, C$ associates to each available store choice option $o \in\{1, \ldots, O\}$ out of a set of shopping alternatives an unobservable, latent preference or utility before choosing the one which yields maximum utility (e.g., McFadden, 1973; Ben-Akiva and Lerman, 1985; Louviere et al., 2000). More specifically, under standard RUT assumptions the latent utility of store $o$ to consumer $c$ in a shopping situation $s$ is assumed to consist of two components:

$$
U_{o c s}=V_{o c s}+\varepsilon_{o c s}
$$

$V_{\text {ocs }}=$ deterministic (observable, explainable) component of utility consumer $c$ associates with store $o$ at shopping occasion $s$. 
$\varepsilon_{o c s}=$ random (unexplainable) component of utility.

The deterministic utility $V_{o c s}$ is represented as an indirect additive function $\mathrm{X}_{o d} \beta^{\prime}$ where $\mathrm{X}_{o c}$ is an $[O \times C, K]$ matrix of individual store specific attributes (in the present case $K$ denotes an index set of store attributes as perceived by shoppers) and $\beta$ is an $K$-dimensional vector of utility parameters or part-worth utilities that represent consumers' trade-offs between store attributes or their sensitivities towards changes in attribute levels that are usually (but not necessarily) under control of retail management. Hence, $V_{o c}$ specifies the composition rule that maps the observed multidimensional attribute vectors on a unidimensional overall utility of the form $V_{o c}=\sum_{k=1}^{K} \beta_{k c} X_{o k c}$.

Each of these individual part-worth utilities $\beta_{k c}$ is represented as a weight that is linked to one specific store attribute $k$ (see Figure 1). Therefore, the weights denote the relative importance shoppers attach to the respective store attributes in their decision making process. Although not explicitly included in the above generic formulation, potential moderating variables are the shopping situation or occasion, awareness of shopping alternatives and consumer background characteristics such as socio-economics, shopping motivation, life-style and personality factors, etc.

Figure 1: An extended random utility framework for explaining store choice

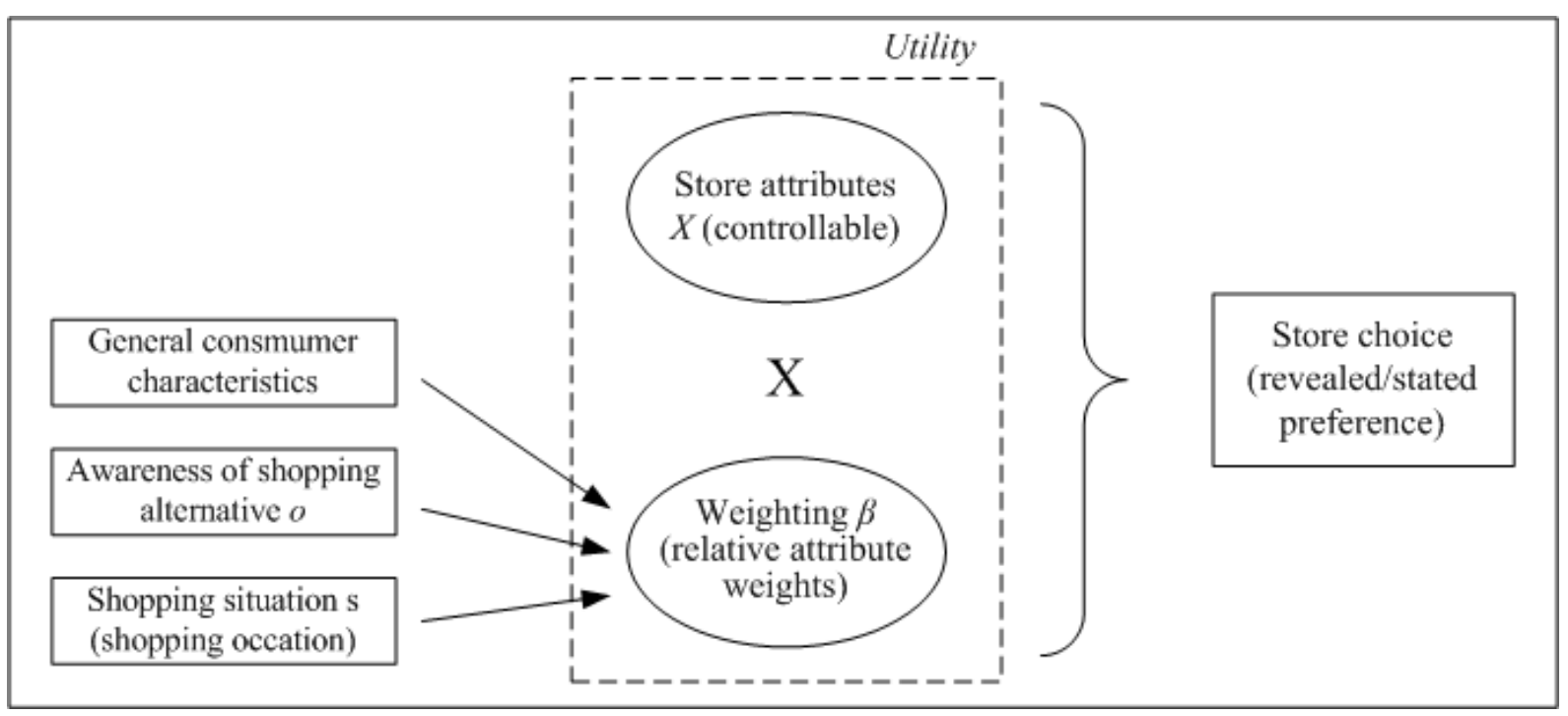


Notice, that suppression of the situation specific label $s$ in the above notation implies that the focus is on perceived psychological attribute values averaged over time, i.e. shopping occasions. However, as Kahn and Schmittlein (1989) and Walters and Jamil (2003) concluded in a more descriptive study, grocery-shopping behaviour may be different depending upon whether consumers are on a major trip to the store or just on a fill-in trip.

Standard multiattribute approaches to explaining store choice require that consumers are aware of all available shopping alternatives once they decide to shop. If this awareness condition is not warranted, i.e. a store is not included in an individual consumer's awareness set, the respondent will also be unable to quote neither valid nor reliable attribute ratings for that shopping alternative. The assumption that each consumer is aware of the total set of available shopping options in the trading area under study is unrealistic. Moreover, as discussed by Shocker et al. (1991) in detail, when studying consumer choice behaviour one can expect the 'universal set' of available choice options to be decomposed into subsequent subsets (denoted as awareness and consideration sets) before the ultimate choice decision occurs. Roberts and Lattin (1991) provide empirical evidence that both size and composition of individual brand consideration sets are a functional trade-off between expected utility improvement and search cost. To account for awareness set heterogeneity across consumers, in the present empirical application for each respondent an individual subset of outlets established in the trading area (denoted as $A_{c} \subseteq O$ ) is determined. In the utility formation process of the store choice model individual choice sets were restricted to those alternatives only, which the respective respondent was aware of.

Whereas the deterministic utility specifies the fashion, individuals are assumed to process information about (physical) store characteristics via introduction of the concept of weight, different assumptions about the distribution and structure of the random or error component of utility $\varepsilon_{o c s}$ lead to different choice models. If, for example, the errors are assumed independent across alternatives and Identically Distributed (IID) Gumbel random variates, we arrive at the well-known and widely applied MultiNomial Logit (MNL) model (e.g., 
McFadden, 1974; Ben-Akiva and Lerman, 1985). It can be shown (without loss of generality) that the probability $P(o, c, s)$ that an individual $c$ chooses a particular store $O$ at shopping situation $s$ is proportional to the ratio of the respective store's (deterministic) utility $V_{\text {ocs }}$ and the sum of the utilities for all alternatives out of the consumer's awareness set $A_{c}$ (e.g., Hensher and Johnson, 1981; Louviere and Woodworth, 1983; Meyer and Eagle, 1982). Assuming IID errors, choice probabilities can be derived by the following relationship:

$$
P(o, c, s)=\frac{\exp \left(\mu_{o c s} V_{o c s}\right)}{\sum_{o=1}^{A_{c}} \exp \left(\mu_{o c s} V_{o c s}\right)}
$$

where $\mu$ is a precision parameter that scales utility differences in general ${ }^{1}$. One of the most appealing properties of assuming IID-error variances (and thus arriving at an MNL model specification) is primarily of computational nature. In contrast to behaviourally possibly more realistic assumptions ${ }^{2}$ about the error term in the utility model (1) a closed-form expression for the choice probabilities allows a fast location of Maximum Likelihood (ML) estimates for the $\beta$ parameters. The function $L$ represents the probability (or likelihood) of getting our observed store choices given a set of certain parameters. Omitting situational effects for the moment and assuming independent observations, the construction of such a likelihood function $L$ involves the joint probability $P(O, C)$ of a store actually chosen by an individual consumer and can be written as follows (e.g., Fotheringham, 1988):

$$
L=\prod_{c=1}^{C} \prod_{o=1}^{A_{c}} P_{o, c}^{f_{o c}} \quad \text { and } \quad L L=\log (L)=\sum_{c=1}^{C} \sum_{o=1}^{A_{c}} f_{o c} \ln P(o, c)
$$

Here, $f_{o c}$ is defined as an indicator variable, such that $f_{o c}=1$ if outlet $c$ is chosen and $f_{o c}=0$ otherwise. Usually, the properties of the joint probability function are such that it is easier to take the logarithm of the likelihood function $L L$, which needs to be minimised. The log-

\footnotetext{
${ }^{1}$ The higher the value of $\mu$, the more deterministic becomes the model; if $\mu=0$ the choice model would be purely stochastic. Since $\mu$ can be shown to be inversely proportional related to the standard deviations of the unobserved effects for the alternatives and the latter are assumed to be distributed identically for identification purposes of the MNL model this parameter can be set to 1 across alternatives (e.g., Ben-Akiva and Lerman 1985; Swait and Louviere 1993).

${ }^{2}$ One prominent alternative is to assume the error distribution to be normal with $\varepsilon_{o c s} \sim N(0, \Sigma)$, which results in a MultiNomial Probit (MNP) choice model. The resulting addition of behaviour realism, however, is at the expense of computational complexity, since derivation of the choice probabilities require the solution of high dimensional integrals, which cannot be evaluated numerically (Keane, 1992).
} 
likelihood is only a function of the unknown parameter values captured by the deterministic utility expression $V_{o c}$ since both the observed perceptions of store characteristics $X_{o c}$ and actual store choices $f_{o c}$ are known. Therefore, it can be minimised with respect to the model's utility parameters.

Probably the most striking features of this model specification are the assumptions of 'Independence of Irrelevant Alternatives' (IAA) as well as the additive utility function being linear in parameters (however, attributes can enter as logarithms or powers as well as a variety of other forms to cover non-linear effects). The IIA property is equivalent to assuming that there is no correlation between the utilities of two alternatives except due to the explanatory variables, i.e. the covariance structure of the error component is expected to be uncorrelated. This property is a direct consequence of the assumption of IID error variances (which posits that the utility ratio between two stores is independent of a change in the consumer's consideration set). Thus, the utility ratio of two stores remains unaffected if an alternative is added or withdrawn, which in both cases would result in an impact proportional to their current market (or choice) shares (e.g., Ben-Akiva and Lerman, 1985). There are numerous examples in the literature that the absence of any competitive market structure beyond share proportions is unrealistic (in a store choice context see, e.g., Fotheringham, $1988)^{1}$. One potential source for violations of the IIA property are situational effects such as shopping occasion (Kahn and Schmittlein, 1989). In order to relax these strong assumptions associated with IID error terms in a way that is behaviourally enriching, computationally tractable and easy to implement, in the subsequent application two different choice variables are collected that differentiate whether a person is planning a major grocery shopping trip or just a fill-in trip and separate MNL choice models are estimated for each of them.

\footnotetext{
${ }^{1}$ Nevertheless, the great majority of empirical consumer research applications are relying on the basic MNL model, which also enjoys much practitioner's support. Furthermore, besides fast convergence the ML estimation procedure has an added advantage of data economy (Louviere et al., 2000).
} 


\section{Hypotheses}

Based on the framework explained above two groups of hypotheses have been derived. They propose a relationship between the shopping occasion and store format choice whereby store format attributes are expected to be predictive of the respective choices. These attributes represent the stereotypical application of (retail) marketing strategies and actions perceived by the consumers. The moderating variable shopping occasion is operationalised by two types of shopping trips, namely a fill-in trip or a major trip. Table 1 characterises these two trip types in an idealised manner.

Table 1: Characterisation of fill-in and major trip (Kahn and Schmittlein, 1992; Kollat and Willet, 1967)

\begin{tabular}{|c|c|c|}
\hline Characterisation & Fill-in trip & Major trip \\
\hline $\begin{array}{l}\text { Urgency (time pressure) of needs and wants to be satisfied by the } \\
\text { consumer }\end{array}$ & High & Low \\
\hline Total shopping efforts (planning, transportation, picking, packaging) & Low & High \\
\hline Dedicated time budget & Small & Large \\
\hline Trip frequency & High (by instance) & Low (regular) \\
\hline Shopping basket & Small & Large \\
\hline
\end{tabular}

Taking into account the basic characterisation of the most important store formats in grocery retailing (e.g., Berman and Evans, 2007; González-Benito, 2001) it can be expected that attributes like store location, accessibility and assortment strongly influence the preference of consumers in dedicating their shares of wallet for each of these two trip types (Solgaard and Hansen, 2003; Popkowski-Leszczyc and Timmermans, 2001; Bhatnagar and Ratchford, 2004). Large scale retail formats in grocery retailing like large supermarkets and hypermarkets tend to be more appropriate to carry out a major trip. They offer a broad and deep assortment and are located in more peripheral areas often providing better parking facilities resulting in increased accessibility for customers using cars (Berman and Evans, 2007; González-Benito, 2001). We therefore set up hypothesis $\mathrm{H}_{1 \mathrm{a}}$ :

$H_{1 a}$ : Consumers' utility values are higher for large scale retail formats compared to small retail formats when undertaking a major trip.

In contrast, small formats like small supermarkets, convenience stores or corner shops offer a broad to medium but narrow assortment and are located near consumers' homes. Thus, 
they are expected to be more capable of satisfying needs of a fill-in trip (Berman and Evans, 2007; Bhatnagar and Ratchford, 2004). This assumption leads to hypothesis $\mathrm{H}_{1 \mathrm{~b}}$ :

$H_{1 b}$ : Consumers' utility values are higher for small retail formats compared to large scale retail formats when undertaking a fill-in trip.

Retail formats can be characterised by similarities in the types of outlets they occupy and the marketing strategy that they adopt. These similarities mean they are competing for a similar perceptual place in the consumers mind. Subsequently we focus on the relative impact of perceived store format attributes on format choice in the two types of shopping trip situations discussed. Table 1 suggests the expectation that consumers undertaking a fill-in trip seek convenience and service, i.e. store format characteristics that make the shopping trip easier and quicker to carry out (Bhatnagar and Ratchford, 2004; Tang et al., 2001; Baron, et. al., 2001). This quite obvious relationship between store format attributes and trip type leads to hypothesis $\mathrm{H}_{2 \mathrm{a}}$ :

$H_{2 a}$ : Service/convenience-related store format attributes have more impact on utility values compared to merchandise-related attributes when undertaking a fill-in trip.

To the contrary, on a major trip consumers tend to look for one-stop or multipurpose shopping possibilities to reduce their shopping endeavours (Tang et al., 2001; GonzálezBenito, 2001; Messinger and Narasimhan, 1997). Consumers therefore are assumed to look for more merchandise-related store format attributes which finally leads to $\mathrm{H}_{2 b}$ :

$H_{2 b}$ : Merchandise-related store format attributes have more impact on utility values compared to service/convenience-related attributes when undertaking a major trip.

To test our hypotheses we set up the following empirical study. 


\section{Empirical Study}

\subsection{Research design}

Data for the present study were collected from a survey of grocery shopping trip behaviour from a (quota) sample of 408 households in an urban retail area in Austria (quota controls: household size, educational level of household leader, location (district)). This area was selected for the following reasons: First, due to particular landscape and traffic access characteristics, the boundaries of its trading area are relatively easy to determine (at least for grocery product categories). Second, within this trading area all the major competitors in the Austrian grocery retail market scene are present with at least one outlet. Finally, the dominating retail formats in that market, i.e. hypermarket, supermarket and discount store, are represented as well whereas smaller formats struggling against the bigger formats.

The person who is mainly responsible for grocery shopping of the respective household acted as the respondent, with about $90 \%$ being female, most of them aged between 34 and 52 years, and living in a household consisting of two $(\sim 10 \%)$, three $(\sim 17 \%)$, four $(\sim 37 \%)$ or five and more ( $26 \%$ ) persons. More than half of the respondents are solely homemakers, about a quarter are white-collar workers. The majority of respondents (about $\sim 80 \%$ ) are married.

The sample can be regarded as being representative with respect to the household structure in the retail market under study. Nevertheless, the respondents do not represent the general population which was not the aim of the sample selection procedure. In that respect our sample is biased towards younger female on a lower educational and professional level which can be explained by the traditional 'role allocations' within households under study (Statistik Austria, 2007).

\subsection{Observed measures of store format choice and predictors}

In order to control for effects due to shopping occasion (or shopping trips), two different store format choice specifications were observed as the dependent variable of the model. 
Consistent with the RUT paradigm, both measures are collected as stated preference data. Respondents were asked to indicate (1) the store preferred (in terms of visited most often) for their major (or high volume) grocery shopping trips and (2) the store visited most often for fill-in trips.

A limited number of store format attributes as perceived by consumers are serving as the choice predictors (see Table 2). The selected format attributes correspond to those most frequently mentioned in the literature (e.g., Gehrt and Yan, 2004; Lindquist, 1974; James, Durand and Dreves, 1976; Hildebrandt, 1988; Samli, 1989). Each respondent was asked to rate her/his perceptions of the grocery stores s/he was aware of (in terms of active or unaided recall) with respect to the store format attributes shown in Table 2 (except item (5)) on a five point rating scale anchored by 'strongly agree' $(=1)$ and 'strongly disagree' $(=5)$. Thus, this evaluation was done on a disaggregated level since consumers could not be expected to differ between or recognise store-formats. The classification of evaluated stores into store-formats was consequently done in the interpretation of the results.

Table 2: Attributes used for measuring store format perceptions

\begin{tabular}{ll}
\hline & (1) Parking space available close to the outlet \\
Service/convenience-related & (2) Short waiting time at the checkout \\
store format attributes & (3) Pleasant atmosphere in the store \\
& (4) Friendly and helpful personnel \\
& (5) (Spatial) distance \\
\hline & (6) High merchandise quality \\
Merchandise-related store & (7) Low prices \\
attributes & (8) Wide range of assortment \\
& (9) Many discounts and special offers
\end{tabular}

Consistent with preliminary work on store (format) choice behaviour, an additional attribute that is frequently considered to be crucial in store choice, namely the distance between a particular consumer's home and the shopping location (e.g., Huff, 1964; Fotheringham, 1988), has been monitored. In order to estimate the respective distances in terms of transportation time, respondents were asked to specify the addresses of their homes as well as the transport mode they typically chose for grocery shopping trips. 
Since store format attributes (1) to (5) are closely related to customer service/convenience and attributes (6) to (9) rather represent product or merchandise-related elements offered by a format, these 'natural groups' of attributes can be summarised as service/conveniencerelated and merchandise-related store format attributes, respectively (Merrilees and Miller, 2001).

\subsection{Awareness and choice sets in the observed retail market}

Table 3 provides a complete list of the grocery stores competing in the trading area of the study and associated choice as well as awareness shares. Most of them are outlets established by major nation-wide Austrian grocery retail companies. According to ACNielsen (2006) data the two market leading grocery retailing groups, namely REWE Austria and SPAR, are dominating the Austrian grocery retailing industry with respective market shares of $\sim 37$ and $\sim 35 \%$. In the trading area considered in the present study however, the SPAR group is traditionally more active than REWE. As a consequence, SPAR has established four and REWE two different store format concepts in the area under study. Table 3 also provides some basic characteristics of the strategic positioning of the competing grocery stores in terms of assortment and outlet size as well as general pricing formats, i.e., HIghLOw (HILO) promotional pricing versus Every-Day-Low-Prices (EDLP). Notice, that there are some smaller-sized convenience-oriented supermarket formats with highly standardised marketing concepts (three of them are run under the SPAR supermarket and three as members of the voluntary chain store concept ADEG), which can be considered as typical neighbourhood locations that are designed to supply local grocery demand. Besides the remaining independent retail outlets with grocery assortments they therefore are included under one choice category option if chosen by respondents.

As expected, the respondents' stated choice shares of the competing stores differ considerably depending on the type of shopping trip planned (major or fill-in). As indicated by the distribution of choice shares given in Table 3 larger-sized grocery store formats, i.e. 
hypermarkets, with wider assortments located at suburban shopping agglomerations with sufficient parking facilities and easy traffic access dominate choice shares for major or highvolume trips, whereas smaller sized store formats like the SPAR and ADEG supermarkets are mostly preferred for day-to-day fill-in trips. However, it should be noticed that consumers might also prefer identical store formats both for their major and fill-in trips. In the present sample 157 respondents (38.5\%) have stated such shared preferences (in terms of firstchoice). On the other hand this figure indicates that a considerable share of respondents patronise more than one store or format for different shopping occasions (Cummins et al., 2008; Findlay and Sparks, 2008; McGoldrick and Andre, 1997).

Table 3: Competing grocery stores included in the study and relative choice/awareness shares (sample size $n=408$ )

\begin{tabular}{|c|c|c|c|c|c|}
\hline \multirow{2}{*}{ Retailer } & \multirow{2}{*}{ Store format ${ }^{\star \star}$} & \multicolumn{2}{|c|}{ Choice share (\%) } & \multirow{2}{*}{$\begin{array}{l}\text { Awareness } \\
\text { share }(\%)\end{array}$} & \multirow{2}{*}{$\begin{array}{l}\text { General store format attributes } \\
\text { (store format) }\end{array}$} \\
\hline & & Major trip & Fill-in trip & & \\
\hline \multirow{2}{*}{ REWE } & (1) $\mathrm{HM}^{\star}$ & 0.33 & 0.12 & 0.84 & $\begin{array}{l}\text { wide assortment, HILO pricing, } \\
\text { size } \sim 2,500 \mathrm{~m}^{2} \text {. }\end{array}$ \\
\hline & (2) SM & 0.01 & 0.02 & 0.29 & $\begin{array}{l}\text { smaller assortment, HILO } \\
\text { pricing, size } \sim 700 \mathrm{~m}^{2} .\end{array}$ \\
\hline \multirow{4}{*}{ SPAR } & (3) $\mathrm{HM} \mathrm{I}^{*}$ & 0.17 & 0.07 & 0.69 & $\begin{array}{l}\text { wide assortment, HILO pricing, } \\
\text { size } \sim 1,500 \mathrm{~m}^{2} .\end{array}$ \\
\hline & (4) $\mathrm{HM} \mathrm{II}$ & 0.17 & 0.12 & 0.67 & $\begin{array}{l}\text { medium/wide assort., HILO } \\
\text { pricing, size } \sim 1,000 \mathrm{~m}^{2} .\end{array}$ \\
\hline & (5) SM & 0.03 & 0.04 & 0.49 & $\begin{array}{l}\text { medium assortment, HILO } \\
\text { pricing, size } \sim 700 \mathrm{~m}^{2} .\end{array}$ \\
\hline & (6) small SMs $(3 \times)^{*}$ & 0.07 & 0.33 & 0.66 & $\begin{array}{l}\text { smaller assortment, HILO } \\
\text { pricing, size }<500 \mathrm{~m}^{2} \text {. }\end{array}$ \\
\hline \multirow[t]{2}{*}{ ALDI } & (7) $\mathrm{DS}^{*}$ & 0.13 & 0.03 & 0.83 & $\begin{array}{l}\text { store label dominant, EDLP, size } \\
\sim 800 \mathrm{~m}^{2} .\end{array}$ \\
\hline & (8) small SMs $(3 \times)^{*}$ & 0.04 & 0.21 & 0.60 & $\begin{array}{l}\text { smaller assortment, HILO } \\
\text { pricing, size }<500 \mathrm{~m}^{2} \text {. }\end{array}$ \\
\hline \multirow[t]{2}{*}{ ADEG } & (9) local DS & 0.03 & 0.04 & 0.40 & $\begin{array}{l}\text { only limited grocery assortment, } \\
\text { EDLP, size } \sim 500 \mathrm{~m}^{2} \text {. }\end{array}$ \\
\hline & (10) Others & 0.02 & 0.04 & 0.21 & $\begin{array}{l}\text { Various small sized } \\
\text { (independent) stores with } \\
\text { grocery assortments. }\end{array}$ \\
\hline
\end{tabular}

There are three stores and the 'others' category with (first) choice shares lower than five per cent both for major and fill-in trips. Possible reasons for these minor shares can be reported for the local discount store and the SPAR supermarket: While the first is offering only a very 
limited grocery (mainly non-food categories) assortment and consequently is only rarely nominated as the first-best choice option the SPAR supermarket is located relatively close to the boundary of the trading area under study or at the intersection with another trading area, respectively. Interestingly, despite its nation-wide marketing support the city centre located REWE supermarket is also facing both extremely low shares of first choice and a comparatively low share of voice (awareness) among respondents, which highlights potential problems with local customer retention policy. Nevertheless, due to their obviously only minor importance for the respondents' preference formation as indicated by their low choice shares outlets (2), (5), (9), and (10) are excluded from further investigations.

For the remaining grocery stores or store formats, respectively, awareness as measured in terms of share of voice (unaided recall) when planning a grocery shopping trip reaches levels of about $60 \%$ of respondents or more. On average, the respondent specific awareness sets consist of five to six outlets (set size mean: 5.7 ; median: 5 ) for the complete outlet set and around four stores (set size mean: 4.3; median: 4) for the reduced set of alternatives. It should be clear from the above discussion on awareness set heterogeneity that only store format attribute perceptions ratings for the reduced set are included in estimating the choice models.

\section{Results}

\subsection{Store format preference and distinct shopping occasions (H1a/b)}

Two separate choice models were specified and estimated for the answers obtained for major trip and fill-in trip situations. In addition to store format attribute parameters a set of store-specific constants were included in the model, with the ADEG supermarket serving as the baseline. The estimation results are depicted in Table 4. From the modelling approach it should be clear that the higher the value of each coefficient for the store-specific constants the more the respective store contributes to the utility formation for a major or a fill-in trip. With the exemption of the '(small) SPAR supermarket' constants, 'merchandise quality' (in 
both models), 'pleasant store atmosphere' (in the major trip model) and 'fast checkout' (in the fill-in trip model) all parameters are statistically significant.

The highest utility contribution regarding major trips was identified for the (ALDI) discount store and all the other hypermarkets (REWE and SPAR) in the observed choice sets. In contrast, the SPAR and ADEG supermarkets have no significant impact on utility. Conversely, by focusing on fill-in trips the (small) ADEG supermarket turns out to be the most preferred shopping alternative whereas all the other coefficients prove to be lower or in the case of the (small) SPAR supermarket of no significance. As one might expect, the discount store turns out to be least preferred for a fill-in trip.

Table 4: Parameter estimates and fit criteria for major and fill-in trip models

\begin{tabular}{|c|c|c|c|c|c|}
\hline \multirow[b]{2}{*}{ Store format } & \multirow[t]{2}{*}{ Parameter } & \multicolumn{2}{|c|}{ Major trip } & \multicolumn{2}{|c|}{ Fill-in trip } \\
\hline & & $\begin{array}{c}\beta \text { (constant) } \\
(\mathrm{SE})\end{array}$ & t-stat. & $\begin{array}{c}\beta \text { (constant) } \\
(\mathrm{SE})\end{array}$ & t-stat. \\
\hline HM (REWE) & & $\begin{array}{l}2.5416 \\
(0.420)\end{array}$ & $6.05^{\star \star}$ & $\begin{array}{c}-1.8041 \\
(0.371)\end{array}$ & $-4.86^{\star \star}$ \\
\hline HM I (SPAR) & & $\begin{array}{l}2.2148 \\
(0.428)\end{array}$ & $5.17^{\star *}$ & $\begin{array}{l}-2.0120 \\
(0.388)\end{array}$ & $-5.18^{* *}$ \\
\hline HM II (SPAR) & & $\begin{array}{l}1.8958 \\
(0.370)\end{array}$ & $5.13^{\star *}$ & $\begin{array}{c}-1.1676 \\
(0.326)\end{array}$ & $-3.58^{* *}$ \\
\hline DS (ALDI) & & $\begin{array}{l}2.6897 \\
(0.535)\end{array}$ & $5.03^{* *}$ & $\begin{array}{l}-2.0567 \\
(0.547)\end{array}$ & $-3.76^{\star *}$ \\
\hline Small SM (SPAR) & & $\begin{array}{l}0.0564 \\
(0.364)\end{array}$ & 0.15 & $\begin{array}{l}-0.1350 \\
(0.213)\end{array}$ & -0.63 \\
\hline Small SM (ADEG) & & 0.0000 & - & 0.0000 & - \\
\hline
\end{tabular}

\begin{tabular}{|c|c|c|c|c|c|c|c|}
\hline \multirow{2}{*}{\multicolumn{2}{|c|}{$\begin{array}{l}\text { Parameter } \\
\text { Store format attributes }{ }^{\mathrm{A}}\end{array}$}} & \multicolumn{3}{|c|}{ Major trip } & \multicolumn{3}{|c|}{ Fill-in trip } \\
\hline & & $\begin{array}{c}\beta \\
(\mathrm{SE})\end{array}$ & t-stat. & Us & $\begin{array}{c}\beta \\
(\mathrm{SE})\end{array}$ & t-stat. & Us \\
\hline \multirow{5}{*}{ 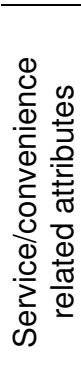 } & $\begin{array}{l}\text { (1) Parking space } \\
\text { availability }\end{array}$ & $\begin{array}{l}-0.2187 \\
(0.098)\end{array}$ & $-2.24^{*}$ & $7.67 \%$ & $\begin{array}{l}-0.2790 \\
(0.104)\end{array}$ & $-2.68^{\star \star}$ & $10.05 \%$ \\
\hline & (2) Fast checkout & $\begin{array}{l}-0.2258 \\
(0.106)\end{array}$ & $-2.12^{*}$ & $7.92 \%$ & $\begin{array}{l}-0.0667 \\
(0.127)\end{array}$ & -0.52 & - \\
\hline & $\begin{array}{l}\text { (3) Pleasant store } \\
\text { atmosphere }\end{array}$ & $\begin{array}{l}-0.1361 \\
(0.124)\end{array}$ & -1.09 & - & $\begin{array}{l}-0.3661 \\
(0.154)\end{array}$ & $-2.38^{*}$ & $13.19 \%$ \\
\hline & (4) Personal service & $\begin{array}{l}-0.3888 \\
(0.111)\end{array}$ & $-3.52^{\star *}$ & $13.64 \%$ & $\begin{array}{r}-0.4602 \\
(0.128)\end{array}$ & $-3.59^{\star *}$ & $16.58 \%$ \\
\hline & (5) (Spatial) distance & $\begin{array}{l}-0.2553 \\
(0.052)\end{array}$ & $-4.94^{\star \star}$ & $8.95 \%$ & $\begin{array}{l}-0.2836 \\
(0.057)\end{array}$ & $-5.01^{\star *}$ & $10.22 \%$ \\
\hline \multirow{4}{*}{ 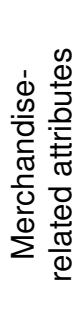 } & $\begin{array}{l}\text { (6) Merchandise } \\
\text { quality }\end{array}$ & $\begin{array}{l}-0.1511 \\
(0.110)\end{array}$ & -1.37 & - & $\begin{array}{l}-0.1885 \\
(0.124)\end{array}$ & -1.53 & - \\
\hline & (7) Low prices & $\begin{array}{l}-0.6165 \\
(0.170)\end{array}$ & $-3.64^{\star *}$ & $21.62 \%$ & $\begin{array}{l}-0.4355 \\
(0.202)\end{array}$ & $-2.16^{*}$ & $15.69 \%$ \\
\hline & $\begin{array}{l}\text { (8) Wide assortment } \\
\text { range }\end{array}$ & $\begin{array}{l}-0.5936 \\
(0.150)\end{array}$ & $-3.97^{\star *}$ & $20.82 \%$ & $\begin{array}{l}-0.5478 \\
(0.158)\end{array}$ & $-3.48^{\star *}$ & $19.74 \%$ \\
\hline & $\begin{array}{l}\text { (9) Discounts \& } \\
\text { special offers }\end{array}$ & $\begin{array}{l}-0.5525 \\
(0.143)\end{array}$ & $-3.87^{\star *}$ & $19.38 \%$ & $\begin{array}{l}-0.4029 \\
(0.164)\end{array}$ & $-2.45^{\star}$ & $14.52 \%$ \\
\hline
\end{tabular}




\begin{tabular}{|c|c|c|}
\hline $\begin{array}{l}\text { Log-likelihood at constant } \\
\text { (LL } \text { const })\end{array}$ & -464.56366 & -368.08326 \\
\hline $\begin{array}{l}\text { Log-likelihood at convergence } \\
\text { (LL conv) }\end{array}$ & -362.97898 & -311.61134 \\
\hline $\begin{array}{l}\text { Pseudo }^{2} \text { (const.) }(1- \\
\left.\text { LL }_{\text {conv }} / L_{\text {const }}\right)\end{array}$ & 0.21867 & 0.15342 \\
\hline Adj. pseudo $\mathrm{R}^{2}$ (const.) & 0.21405 & 0.14842 \\
\hline
\end{tabular}

Caption: HM...hypermarket, SM...supermarket, DS...discount store; B...coefficient; SE...standard error;

t-stat...t-statistics; * $\left.{ }^{* *}\right) \ldots 95 \%(99 \%)$ confidence; Us...utility share; A...based on a 5point rating scale ( $1=$ strongly agree; $5=$ strongly disagree); Diff.....significant differences between coefficients

As a first major result large scale store formats are the preferred option when consumers are undertaking major trips and small ones when fill-in trips are carried out. These results widely correspond with both the above presented choice shares and the marketing strategic focus of the retail formats under investigation. We therefore can accept both hypotheses $\mathrm{H}_{1 \mathrm{a}}$ and $\mathrm{H}_{1 \mathrm{~b}}$

\subsection{Store format attributes and distinct shopping occasions (H2a/b)}

Next, we explore the comparative importance of the diverse store format attributes for different kinds of shopping trips. When interpreting the store format attribute parameters it should be noticed that smaller values indicate a higher impact on the deterministic component of utilities. This is because of the way attributes were rated in the underlying survey. As expected, every coefficient shows a negative sign. To make the estimates easier to compare across the models for the two shopping trip types, we provide a more comprehensive presentation of the role each attribute plays in the utility expression. In doing so, the percentages right beside the utility parameters $\beta$ (indicated in Table 4) refer to the respective relative impact on store choices accounted for by a single store format attribute. For computation of these percentages, the sum of all statistically significant weighting parameters has been re-scaled to the sum of 100 . Hence, for each model the ratio of two percentages is equivalent to the ratio of the original parameter values $\beta_{k}$ under consideration. 
In sum, the merchandise-related attributes considered in our study explain half ( $50 \%)$ of the utility formation in the fill-in trip store format choice model. This is much less than the about $62 \%$ impact on deterministic utility in the case of the major trip model. Even more important, both price-related attributes ('low prices' and 'discounts') contribute significantly higher to the utility for conducting a major trip as opposed to a fill-in-trip where 'assortment width' is the most important store format attribute. With the exception of the attribute 'merchandise quality' we therefore can accept hypothesis $\mathrm{H}_{2 \mathrm{~b}}$.

When looking at the service/convenience-related attributes we face a more divergent picture. Both models indicate 'personal service' as being most important for utility formation. Apart from 'fast checkout' all other attributes deliver higher utilities when conducting a fill-in trip. The most discriminating attribute is represented by 'pleasant store atmosphere' which is of no significance in the major trip model. Overall the results show that service and convenience related attributes together explain about $50 \%$ of the deterministic utility for fill-in trips, which is significantly higher compared to the major trip store format choices $(\sim 38 \%)$. Except for the attribute 'fast checkout' we can accept hypothesis $\mathrm{H}_{2 a}$.

\section{Conclusions}

\subsection{Synopsis}

We discussed and applied models of store format choice that relate a variant of discrete choice variables (here: store formats chosen for major or fill-in trips, respectively) to consumers' perceptions with respect to a set of store format attributes in an RUT framework. The estimation results indicate that multiattribute models for store format choice fit well. The proposed model generated some interesting insights into the preference formation process underlying consumers' store format choice decisions in grocery retailing. The results of testing two sets of hypotheses can be retrieved from Table 5.

Table 5: Results from hypotheses testing

\begin{tabular}{llc}
\hline$\#$ & Hypotheses & accepted/rejected \\
\hline $\mathrm{H}_{1 \mathrm{a}}$ & Consumers' utility values are higher for large scale retail formats compared to & accepted \\
& small retail formats when undertaking a major trip. & \\
$\mathrm{H}_{1 \mathrm{~b}}:$ & Consumers' utility values are higher for small retail formats compared to large & accepted \\
\hline
\end{tabular}




\begin{tabular}{lll}
\hline $\mathrm{H}_{2 \mathrm{a}}:$ & $\begin{array}{l}\text { scale retail formats when undertaking a fill-in trip. } \\
\text { Service/convenience-related store format attributes have more impact on utility } \\
\text { values compared to merchandise-related attributes when undertaking a fill-in trip. }\end{array}$ & Partly accepted \\
$\mathrm{H}_{2 \mathrm{~b}}:$ & $\begin{array}{l}\text { Merchandise-related store format attributes have more impact on utility values } \\
\text { compared to service/convenience-related attributes when undertaking a major } \\
\text { trip. }\end{array}$ & Partly accepted \\
\hline
\end{tabular}

The differences in the part-worth utilities (importance weights) of perceived store format attributes have been shown to be conditional on whether a store is selected for a major grocery shopping trip or a store is selected for a fill-in trip. These findings are in line with findings of similar studies in the literature (e.g., Walters and Jamil, 2003; PopkowskiLeszczyc and Timmermans, 2001; Kahn and Schmittlein, 1989/1992; Tang et al., 2001; Baron, et. al., 2001). Unlike these, we argue and investigate on an aggregated level by looking at store formats. In doing so we additionally take into consideration that customers patronise more than one retail format when shopping groceries (McGoldrick and Andre, 1997).

In case of major trips, consumers chose large scale retail formats such as discounters $(>800$ $\mathrm{m}^{2}$ ) but also hypermarkets $\left(>1,000 \mathrm{~m}^{2}\right)$ because of superior expectation about assortment, price and discounts or special offers, i.e. merchandise-related store format attributes. Small scale retail formats $\left(<500 \mathrm{~m}^{2}\right)$, such as small supermarkets, are preferred for fill-in trips, whereas 'personal service' and 'store atmosphere' deliver a higher share of utility compared to major trips. By applying a more general view, our results also confirm the notions of Van Kenhove et al. (1999) and Gehrt and Yan (2004). They show a significant impact of the task definition - here operationilised by the different shopping trip types - on the store format choice in a grocery retailing context. Furthermore, store format attributes reflecting the applied marketing strategies and actions of retailers contribute distinctively to shoppers' utilities when they plan and fulfil different kind of shopping tasks. Therefore, they prove to be accurate predictors for dedicating the grocery related share of grocery shopping related spending to different store formats.

\subsection{Managerial implications}


Consistent with most of the current marketing practices, our empirical findings imply that smaller retailers operating small formats should avoid any direct competition with their larger scaled rivals that relies on non-service, typically merchandise-related elements of the retail mix, such as 'price' or 'merchandise quality'. In the case of everyday grocery shopping (fill-in trip), these store format attributes explain only comparatively small portions of observed store choices as opposed to high volume (major) trips. On the other side, our findings also provide empirical evidence that smaller-sized grocery store formats, mostly located in urban areas, are able to (re-)gain competitive advantage vis-à-vis their large-scale counterparts by focusing on service-driven marketing concepts that reinforce relationships with their customers. Dimensions for creating value to potential customers are 'store atmosphere' and 'quality of sales personnel'.

Since the results suggest that customers may patronise different store formats depending on the respective shopping trip type it also turns out to be important for retail managers to learn more about their customer-mix and to understand in more detail for which shopping trip their stores or store formats are primarily chosen by their clientele. A specification of such typical shopping trip, resulting in different sizes (and values) of shopping baskets, sought price levels, urgency of needs, etc., when applying or adapting marketing strategies of store formats, should be carefully considered (Van Kenhove et al., 1999). In this respect, knowledge about the relative weights or part-worth utilities consumers attach to specific store format attributes provide a valuable basis for the retailers' decision-making on how to allocate funds and efforts within the store format strategy and the derived marketing mix.

\subsection{Limitations and outlook for further research}

Although the observed retail market seemed to be appropriate for an empirical application of our model because of its clear boundaries, it is important to notice that the grocery retail business and therefore the phenomenon of store format competition is rather local and country specific. Hence, a replication of the study in other retail areas might lead to different 
results. Further research could therefore focus on markets where, for example, store density, retail concentration and the distribution of large scale or small retail formats are different compared to the one under study.

Furthermore, it should also be noted that the effects modelled in our empirical application pertain to consumer perceptions of grocery store format attributes (with the exception of home-to-store distances), which are not always directly controllable by retail managers. Hence, it would be extremely useful to identify more objective, measurable and actionable factors that map into each of the perceptual attributes. Using the concept of information integration, Louviere and Gaeth (1987) provide a demonstration of how such 'psychophysical' functions that link objective and perceptual measures could be estimated (Timmermans, 1982).

As another shortcoming of the presented research work it has to be mentioned that we did not differentiate between customer and household groups in our sample. Based on the suggestions of Louviere et al. (2000) and as an extension of existing results a segmentation could be done by comparing customer segments based on socio-demographic and/or psychographic criteria. Further research could therefore focus on the impact of such moderating variables on the relationship between shopping occasion and store format preference (Home, 2002).

\section{References}

ACNielsen (2004), Europe: Format evolution. Internal presentation of ACNielsen, ACNielsen Austria, Vienna.

ACNielsen (2006), Statistisches Jahrbuch 2005, ACNielsen Austria, Vienna.

Baron, S., Harris, K., Leaver, D., Oldfield, B. M. (2001), "Beyond convenience: the future for independent food and grocery retailer in the UK", International Review of Retail, Distribution and Consumer Research, Vol. 11 No. 4, pp. 395-414.

Ben-Akiva, M. and Lerman, S. (1985), Discrete choice analysis: Theory and application to travel demand, MIT-Press, Cambridge. 
Berman, B. and Evans, J. R. (2007), Retail management. A strategic approach, Pearson Prentice Hall, Upper Saddle River NJ.

Bhatnagar, A. and Ratchford B. T. (2004), "A model of retail format competition for nondurable goods", International Journal of Research in Marketing, Vol. 21 No. 1, pp. 39-59.

Colla, E., (2004), "The outlook for European grocery retailing: Competition and format development", International Review of Retail, Distribution and Consumer Research, Vol. 14 No. 1 , pp. 47-69.

Cummins, S., Findlay, A., Petticrew, M. and Sparks, L. (2008), "Retail-led regeneration and store-switching behaviour", Journal of Retailing and Consumer Services, Vol. 15 No. 4, pp. 288-95.

Findlay, A. and Sparks, L. (2008), "Switched": store-switching behaviours", International Journal of Retail \& Distribution Management, Vol. 36 No. 4/5, pp. 375-86.

Fotheringham, A. (1988), "Consumer store choice and choice set definition" Marketing Science, Vol. 7 No. 3, pp. 299-310.

Gehrt, K. C. and Yan R. N. (2004), "Situational, consumer, and retailer factors affecting Internet, catalog, and store shopping", International Journal of Retail \& Distribution Management, Vol. 32 No.1, pp. 5-18.

González-Benito, Ó., (2001), "Inter-format spatial competition of Spanish hypermarkets", International Review of Retail, Distribution and Consumer Research, Vol. 11 No. 1, pp. $63-81$.

González-Benito, Ó., Muñoz-Gallego, P. A. and Kopalle, P. K. (2005), "Asymmetric competition in retail store formats: Evaluating inter- and intra-format spatial effects", Journal of Retailing, Vol. 81 No. 1, pp. 59-73.

Hensher, D.A. and Johnson, L. (1981), Applied discrete choice modelling, (London: Croom Helm).

Hildebrandt, L. (1988), "Store image and the prediction of performance in retailing", Journal of Business Research, Vol. 17 No. 1, pp. 91-100.

Home, N., (2002) "Rural consumers' patronage behaviour in Finland", International Review of Retail, Distribution and Consumer Research, Vol. 12 No. 2, pp. 149-164. 
Huff, D.L. (1964), “Defining and estimating a trade area”, Journal of Marketing, Vol. 28 No. 3, pp. 29-37.

James, L., Durand, M. and Dreves, R.A. (1976), "The use of a multiattribute model in a store image study", Journal of Retailing, Vol. 52 No. 2, pp. 23-32.

Kahn, B.E. and Schmittlein, D.C. (1989), "Shopping trip behavior: An empirical investigation", Marketing Letters, Vol. 1 No. 4, pp. 55-70.

Kahn, B.E. and Schmittlein, D.C. (1992), "The relationship between purchases made on promotion and shopping trip behavior". Journal of Retailing, Vol. 68 No. 3, pp. 294-315.

Keane, M.P. (1992), "A note on identification in the multinomial probit model", Journal of Business \& Economic Statistics, Vol. 10 No. 2, pp. 193-200.

Lindquist, D. (1974) "Meaning of image", Journal of Retailing, Vol. 50 No. 4, pp. 29-38.

Louviere, J. and Woodworth, G. (1983), "Design and analysis of simulated consumer choice or allocation experiments: An approach based on aggregate data", Journal of Marketing Research, Vol. 20 No. 4, pp. 350-367.

Louviere, J.J. and Gaeth, G.J. (1987), "Decomposing the determinants of retail facility choice using the method of hierarchical information integration: A supermarket illustration", Journal of Retailing, Vol. 63 No. 1, pp. 25-48.

Louviere, J.J., Hensher, D.A. and Swait, J.D. (2000), Stated choice models. Analysis and applications, Cambridge University Press, Cambridge.

McFadden, D. (1973), "Conditional logit analysis of qualitative choice behavior", Zarembka, P. (Ed.), Frontiers in Econometrics, Academic Press, New York, pp. 105-142.

McGoldrick, P. J. and Andre, E. (1997), "Consumer misbehaviour: Promiscuity or loyalty in grocery shopping", Journal of Retailing and Consumer Services, Vol. 4 No. 2, pp. 73-81.

Messinger, P. R. and Narasimhan C. (1997), "A model of retail formats based on consumers'economizing on shopping time", Marketing Science, Vol. 16 No. 1, pp. 1-23.

Meyer, R.J. and Eagle, C. (1982), "Context-induced parameter instability in a disaggregatestochastic model of store choice", Journal of Marketing Research, Vol. 19 No. 1, pp. $62-$ 71. 
Merilees, B. and Miller D. (2001), "Superstore interactivity: a new self-service paradigm of retail service?", International Journal of Retail \& Distribution Management, Vol. 29, No. 8/9, pp. 379-389.

Popkowski-Leszczyc , P. T. L. and Timmermans, H. (2001), "Experimental choice analysis of shopping strategies", Journal of Retailing, Vol. 77 No. 4, pp. 493-509.

Roberts, J.H. and Lattin, J.M. (1991), "Development and testing of a model of consideration set composition", Journal of Marketing Research, Vol. 28 No. 4, pp. 429-440.

Samli, A.C. (1989), "Store image definition. Dimensions, measurement and management", Samli. A.C. (ed.) Retail marketing strategy, Quorum, New York.

Shocker, A.D., Ben-Akiva, M., Boccata, B. and Nedungadi. P. (1991), "Consideration set influence on consumer decision-making and choice: Issues, models, and suggestions", Marketing Letters, Vol. 2 No. 3, pp. 181-197.

Solgaard, H. S. and Hansen T. (2003), "A hierarchical Bayes model of choice between supermarket formats", Journal of Retailing and Consumer Services, Vol. 10 No. 3, pp. 169-80.

Statistik Austria (2007), Statistisches Jahrbuch Oesterreichs 2006 [statistical yearbook of Austria 2006]. (Vienna, Verlag Oesterreich).

Tang, C. S., Bell D. R. and Teck-Hua, H. (2001), "Store choice and shopping behavior: How price format works", California Management Review, Vol. 43 No. 2, pp. 56-74.

Timmermans, H.J.P. (1982), "Consumer choice of shopping centre: An information integration approach", Regional Studies, Vol. 16 No. 3, pp. 171-182.

Uncles, M. and Hammond, K. (1995), "Grocery store patronage", International Review of Retail, Distribution \& Consumer Research, Vol. 5 No. 3, pp. 287-302.

Van Kenhove, P., De Wulf, K. and Van Waterschoot, W. (1999), "The impact of task definition on store-attribute saliences and store choice", Journal of Retailing, Vol. 75 No. 1 , pp. $125-137$. 
Walters, R. G. and Jamil, M. (2003), "Exploring the relationships between shopping trip type, purchases of products on promotion, and shopping basket profit”, Journal of Business Research, Vol. 56 No. 1, pp. 17-29. 